\title{
Towards Sustainability of Real Estate Development: An Integrative Review of Smart City Planning Considerations
}

\author{
Chioma Okoro ${ }^{1}$, Andre Kruger and Marno Booyens
}

1 Finance and Investment Management Department, College of Business and Economics, University of Johannesburg, South Africa, chiomao@uj.ac.za

2 Finance and Investment Management Department, College of Business and Economics, University of Johannesburg, South Africa, akruger@uj.ac.za

3 Finance and Investment Management Department, College of Business and Economics, University of Johannesburg, South Africa, marnob@uj.ac.za

\begin{abstract}
With the ever-increasing urban sprawl in African cities, more attention should be paid to the provision of real estate infrastructure to cater for the population. Ways to harness Africa's possibilities and leverage the opportunities available in the fourth industrial revolution, to diminish housing infrastructure backlogs, warrant consideration. The current study therefore aims to identify the factors that influence the sustainability of real estate developments in recent times, with attention to the planning considerations. An integrative review was conducted with literature from databases including Scopus, Google, Google Scholar, Publish or Perish, Academic Search Complete and Emerald. Synthesis was undertaken using thematic content analysis to identify themes on the factors influencing real estate developments and its sustainability. The distillation of literature revealed that institutional and economic factors were considered the most important factors, while developer's attitude and socio-cultural factors were the least occurring among the sampled literature. By establishing these factors, the current study provides important information for housing and construction stakeholders to be informed and guided in the planning and implementation of real estate development policies in order to provide for and sustain the needs of the current population and future generations given the need for smart cities.
\end{abstract}

(c) 2020 The Authors. Published by Budapest University of Technology and Economics \& Diamond Congress Ltd Peer-review under responsibility of the Scientific Committee of the Creative Construction Conference 2020.

Keywords: development, real estate, smart city, sustainability, urban housing

\section{Introduction}

The construction sector and the property market (the real economy part) are important for meeting mass housing demand and thus are pillars of the country's economic growth [1,2]. The real estate industry generally supports the core business of organisations and the services sector in particular, to provide for the citizenry and contribute significantly to national growth [1]. The performance of real estate developments has primarily been assessed based on periodical returns or appreciation, which are calculated based on the difference of log-prices in time, or fluctuations in transaction prices in liquid markets as used in investment markets [3, 4]. Indices from transaction-based and valuation-based approaches, which are sometimes difficult to predict or estimate, subject to bias (with the use of historical comparable), and extremely scarce from infrequently-trades assets such as real estate, have been used for modelling and market studies over long terms. However, real estate is no longer just about the cyclical undulation of returns. The impact of demographic, social and technological trends on the built environment is coming to the fore of real estate investment decisions and development patterns [5]. To enable the real estate sector to develop in a healthy and sustainable manner, strategies geared toward the future 
sustainability of such projects need to be developed, especially at the time of planning for such developments, in order to create smart cities.

Smart cities host investments in infrastructure, which drive sustainable socio-economic development and improved quality of life for citizens [6]. Therefore, constructing smart cities could have evolutionary consequences for the real estate business since it can add value to properties, as well as boost consumer trust, profit yields and market competition [6]. Hence, the process of real estate development should be guided by participatory and engagement approaches holistically involving consideration of factors that will affect its sustainability. This is especially important given that real estate demand is moving more quickly in recent times than at any other point [5]. According to new data from the U.S. Housing and Urban Development and Commerce Department, total new construction increased 3.8 percent in October 2019 to a seasonally adjusted annual rate of 1.31 million units, 8.5\% higher than in 2018 [7]. This was partly due to numerous factors, which affect the supply and demand, and in turn the prices of homes. Concerns abound among real estate investors, around economic uncertainty and at the same time, they are forced to overhaul traditional business and valuation models in response to rapidly-changing consumer demands [5]. Nevertheless, top cities for real estate investment in 2019 were in Canada, Europe, Asia Pacific and United States [5]. This suggests that Africa is being left behind despite the increasing urban sprawl in most cities. With the rapid growth of African cities, it is estimated that 1.2 billion people, or 60 of Africans, will live in urban areas by 2050. Although, urbanisation is a positive force underpinning grave social, political and economic transformation, the challenge is to help Africa to better harness the productive potential of their cities and to cope with the increased demands for decent housing and municipal services [8,9]. The rapid and projected urbanisation poses substantial and exceptional challenges with regard to sustainability [10]. Therefore, the question that arises is "what factors influence real estate investments in Africa and should be considered in the planning of such developments, in order to find ways to mitigate their impact in the long run?

Previous studies have focused on locational factors for real estate developments [11]; returns on investment [4] and real estate investment decision factors in Malaysia [12]. Other studies dwelt on liquidity of real estate assets and the role of real estate investment trusts (REITs) as a partial hedge against flight-tosafety with regard to risky assets [13]; as well as legislation around REITs [14]. Likewise, different kinds of risk that should be assessed in commercial real estate developments including land cost (usability, restrictions, local authorities, etc.), financial risk (interest rates, delays, etc.), construction (late changes, big financial risk, exposure, etc.), delays, and sale/rents (faulty assumptions) were identified [15]. However, these studies were singularly focused on factors affecting either a decision to purchase or a particular type of property. Further, [1] and [14] focused on entity's performance, which may be limited in scope on what is desirable in smart city real estate development. The current study broadly identifies factors that affect real estate investments and therefore development patterns, and which should be considered at the planning stage in order to achieve sustainable smart cities. Projects have a greater chance to succeed if appropriate and adequate time and effort are committed to the planning stage to understand challenges/risks and opportunities that might be present throughout the project [16]. The current study reviews extant evidence to identify contemporary ways of helping Africa to deal with its housing infrastructure backlog and sustain real estate investments. The results from this integrative review could contribute to the development of planning and implementation strategies for the sustainability of the real estate sector.

\section{Review of literature}

\subsection{Sustainability of real estate developments}

Real estate developments, globally, attract huge financial investment in recent years [17]. The real estate investment space comprises direct (residential, retail, commercial and industrial), indirect (REITS, mortgagebacked securities, property company securities, etc.) and synthetic (such as index notes, return swaps and forwards) properties [18]. Direct real estate investment, which is the focus in the current study, is a multidimensional process with activities ranging from the restoration of brownfield sites to the purchase of raw land to the renovation of existing buildings and to the sale of serviced sites [16]. 
In practice, the real estate asset market generally involves a relatively favourable risk or reward profile, with relatively low liquidity (ease of entry and exit) [19]. It is also inefficient and hard to price or predict accurately [18]. However, the sustainability of real estate has to do with more than price; it encompasses reliability, technology, effectiveness, environmental effects, as well as governance and policy issues, optimal management, finance issues, adaptation and redevelopment [17]. These are aligned with the triple-bottom line, encompassing environmental, social and financial aspects for sustainability in cities [17]. Consequently, appropriate planning should be undertaken, especially at the ideation or conception stage of such projects, where opportunities are identified, designed and planned for [16]. Beyond that, to design, construction, hand-over and letting or occupying the building, risk is a common feature [15].

Value creation in developing real estate assets derives from providing usable space over time with associated services [20]. However, value is mostly created at the ideation stage more than at any other phase in the real estate development process (Figure 1) [16]. This suggests that unpacking the conceptualisation activity, which permits the identification of sub-issues or tasks, with the perception or recognition that opportunities and/or risks exist, is paramount to the success and sustainability of real estate developments. Projects have a greater chance to succeed if appropriate and adequate time and effort are committed to the planning stage to understand challenges/risks and opportunities that might be present throughout the project [16]. Therefore, plans to support environmental sustainability, increase the value of assets, and improve the wellbeing and productivity of users, all at limited costs, should be made at the planning stage in order to ensure achievement of desired outcomes from real estate investments [1]. All potential risks to the project, which may be systematic or uncontrollable (for example, market risk, interest risk) and/or unsystematic should be identified [15]. These may include operational, business, transactional, reputational and developmental risks to the project. However, ultimately, the price that a property commands should reflect the benefits, which justify that the project is worthwhile [20].

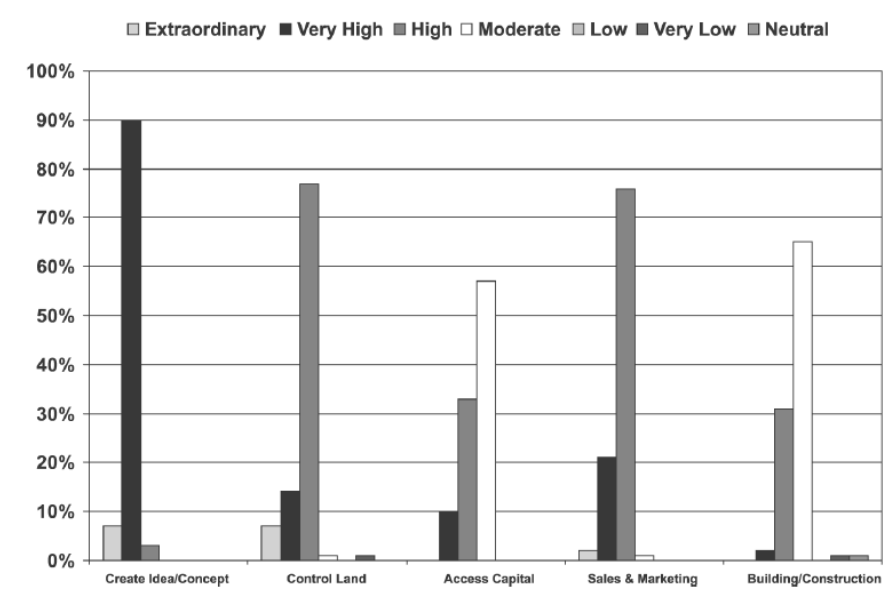

Fig. 1. Value creation at different stages of real estate development [16]

\subsection{Smart city and real estate sustainability}

Smart cities are sometimes deliberated to be about new technologies and opportunities/solutions, which they bring. However, smart cities are much more than technology and are related to sustainability [17], [21]. The smart city is an iteration of a highly modern impetus to imagine and shape the future of the city and of urban society [21]. A city is considered smart if it has one or several initiatives to develop an economy, governance, mobility and/or sustainable housing, among other factors [22]. This is especially the case with real estate investment where value is determined (created or destroyed) by a myriad of factors including globalisation and exposure to emerging economies, sustainability (energy-efficient and water-saving strategies), and innovation (advancement in new technologies and information sharing, availing real-time data) [18]. Further, the anticipated growth of cities creates unprecedented sustainability challenges, increasing demands for basic services (energy, water, sanitation, education, healthcare, housing, transport and public service) and testing the limits of city infrastructures. In 2015, 828 million people lived in temporary housing that lack basic services like sanitation and access to drinking water [23]. In addition, other externalities such as government policies and stakeholders, and availability of financial incentives 
and recourse influence real estate development [16]. Therefore, smart city should also involve a continuous transformative process, based on stakeholder engagement and collaboration, and building different types of human, institutional and technical capacities, driven by public value in all economic, environmental, social, ecological, and political dimensions [23].

The construction of smart cities therefore has possibly evolutionary consequences for the real estate industry sustainability, as this can boost the real estate market, add value to properties, and thus exponentially increase profit yields, consumer trust, and fierce market competition [6]. Advances in information technology provide the necessary tools to complement global real estate developments and smart city orientations [18]. However, the vision of smart city should not focus merely on technological development, but also highlight improvements in the economic, social, cultural, ecological, and governance dimensions, given the high market instability and unreliable nature of real estate developments [6], [23].

Although traditional approaches to risk assessments have been used (such as risk matrix ioMosaic, Bayesian belief network, Monte Carlo simulation and multi-criteria decision analysis), they mostly depend on results derived from either panel discussions or the ranking method, which are not always convincing enough due to the lack of quantitative measurements and strong theoretical bases [15]. In addition, the DCF/NPV techniques do not highlight the added value from managerial factors and flexibility [20]. Consequently, the factors that could potentially affect the sustainability of real estate projects should be identified in order to adequately plan and make reliable decisions as well as develop strategies to mitigate their impact. These findings are presented in a subsequent section, following a discourse on the data collection and analytical techniques employed to achieve the objective of the study.

\section{Materials and methods}

To achieve the objective of the current study, an integrative literature review was undertaken. A literature review was contemplated to assess and synthesize collective evidence from various articles from different sources on factors affecting real estate investments [24]. Since the review aimed to evaluate current knowledge on a particular topic, identify, analyse and synthesize important aspects of real estate investments from independent studies and reveal what questions can be addressed from identifying these factors, an integrative approach was deemed suitable [10], [25], [26].

The review followed a phased approach as outlined by [25]. First, relevant keywords including real estate, investment, housing and development, were used based on the guiding research question and thus results of interest. The keywords were used in conjunction with demand, supply, and pricing, in various permutations. Databases including Scopus, Google, Google Scholar, Publish or Perish, Academic Search Complete and Emerald, were subsequently used to identify relevant articles. These databases were available to the researchers from the university's repository. Articles, including journals, conference proceedings, and online articles, were sought according to their currency (mostly articles spanning over a 10-year publication period) and possession of the relevant keywords. The identified articles were thereafter synthesized using thematic content analysis, to extract factors affecting real estate investment and development and explicate their import in a subsequent discourse. The frequency of occurrence of the factors among the sampled literature was also noted, where a higher frequency was deemed the most important among the sampled literature.

\section{Factors affecting real estate development and investment}

Real estate development and investment decisions are influenced by location, demographic factors (location and neighbourhood characteristics, income level, household size and structure, satisfaction, affordability (home prices and living costs), value of property, home ownership rules [19], [27], [28]. However, these factors mainly influence the decision to purchase or invest in new property in a particular location, or alternative investments (indirect and synthetic property). Other studies identified environmental, social, economic, technological, and political risks as broad factors, which pose risks to commercial real estate developments [5], [15]. The factors identified in this section are focused on direct real estate investments and factors that influence their development patterns. These factors are summarised in table 1. From the table, it can be seen that institutional factors occurred the most among 
the sampled literature, followed by economic factors. The least occurring factors were developer's attitude and socio-cultural factors. These findings are further discussed.

Table 1. Findings on factors affecting real estate development and investment.

\begin{tabular}{|c|c|c|c|c|c|c|c|c|}
\hline \multicolumn{9}{|c|}{ FACTORS } \\
\hline LITERATURE SOURCES & & 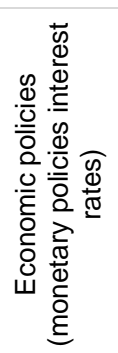 & 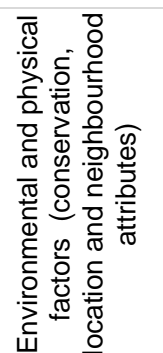 & 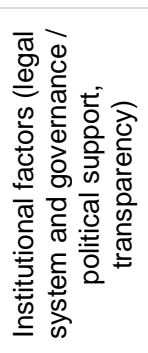 & 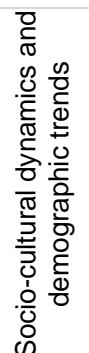 & 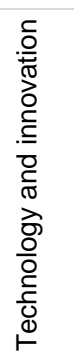 & 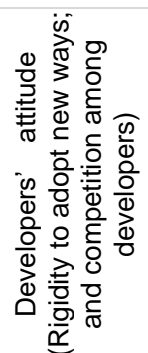 & 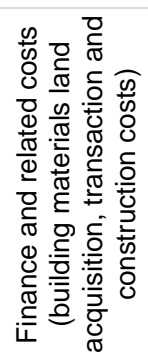 \\
\hline Adegoke & 2014 & $x$ & $x$ & $\mathrm{X}$ & $x$ & & & \\
\hline Bah et al. & 2018 & $\mathrm{x}$ & & & & & & \\
\hline Baldi & 2013 & & & $x$ & & $\mathrm{x}$ & & $\mathrm{x}$ \\
\hline Boudry et al. & 2018 & & & & & & & $\mathrm{x}$ \\
\hline Boudry et al. & 2019 & $x$ & & & & & & \\
\hline Caprotti & 2019 & & & $\mathrm{x}$ & & $\mathrm{x}$ & & \\
\hline Carstens and Wesson & 2019 & $\mathrm{x}$ & & & & & & \\
\hline Carnoske et al. & 2010 & & & $x$ & & $\mathrm{x}$ & $\mathrm{x}$ & \\
\hline Delmendo & 2019 & $x$ & & $x$ & & & & $x$ \\
\hline Edelstein et al. & 2011 & & & $\mathrm{x}$ & & & & \\
\hline Eproperty News & 2018 & & & $\mathrm{x}$ & & & & \\
\hline Fereidouni \& Masron & 2013 & $x$ & & $x$ & & & & $x$ \\
\hline Gavu \& Owusu-Ansah & 2018 & & & $\mathrm{x}$ & & & & \\
\hline Liedtke & 2018 & & & & & $\mathrm{x}$ & & \\
\hline Mariadas et al. & 2016 & & $\mathrm{x}$ & & & & & $x$ \\
\hline Odunsi & 2015 & $\mathrm{x}$ & & & & & & \\
\hline Oloke et al. & 2013 & & $\mathrm{x}$ & & & & & \\
\hline Owusu-Ansah & 2014 & $\mathrm{x}$ & & $x$ & & & & $x$ \\
\hline Owusu-Ansah et al. & 2018 & $\mathrm{x}$ & & & & & & $\mathrm{x}$ \\
\hline $\begin{array}{l}\text { PWC } \\
\text { PWC }\end{array}$ & 2019 & $\hat{x}$ & $\mathrm{x}$ & $\mathrm{x}$ & $\mathrm{x}$ & $\mathrm{x}$ & & $\hat{x}$ \\
\hline Ramabodu et al. & 2007 & $\mathrm{x}$ & $\mathrm{x}$ & $\mathrm{x}$ & $\mathrm{x}$ & & & \\
\hline Roulac et al. & 2006 & $\mathrm{x}$ & & $\mathrm{x}$ & & & & $\mathrm{x}$ \\
\hline Seth & 2017 & & $\mathrm{X}$ & & & & & \\
\hline Thilini \& Wickramaarachchi & 2019 & $x$ & $\mathrm{x}$ & $\mathrm{x}$ & $\mathrm{x}$ & $x$ & & $x$ \\
\hline Tiwari \& White & 2014 & & $x$ & & & $x$ & & \\
\hline Turner & 2017 & & & & & & $x$ & \\
\hline Ullah et al. & 2018 & & & & & $\mathrm{x}$ & $\mathrm{x}$ & \\
\hline WEF & 2016 & & & $x$ & & $x$ & & \\
\hline Williams & 2006 & & & & $x$ & & & \\
\hline Frequency of occurrence & & 13 & 8 & 15 & 5 & 9 & 3 & 10 \\
\hline
\end{tabular}

\subsection{Institutional factors}

Institutional factors including the legal system, transparency, governance and political support influence the extent of real estate investment and development [20], [29]. The high attention given to the collective "institutional factor" may be due to its many facets and associated grave impacts which a proposed or existing real estate project could face if favourable conditions do not exist in a country, as discussed below.

\subsubsection{Legal system}

A country's legal system can generate the necessary protection for investors, or conversely, impose restrictions on the behavior of investors and developers through laws, liability standards and enforcement procedures [29]. For the real estate sector, a well-functioning legal system provides socially beneficial risk reduction in the capital market as well as in the operations of real estate companies, where asset acquisitions and dispositions require consistent legal and regulatory frameworks that insure property rights [29]. 


\subsubsection{Transparency}

Transparency encourages investment. Governance mechanisms can also ensure that shareholders receive transparent, appropriate information about returns on their investments [29]. Governments are increasingly recognising how a transparent real estate market can boost foreign direct investment, increase business efficiencies, enhance living standards as well as support and maintain a safe environment [30]. It is imperative for long-term planning, economic growth and investment in high-quality urban infrastructure and housing. Operational "transparency" can also benefit investors by improving their understanding of real estate company performance. In theory, a country with a superior legal system would lower the risk premiums required by real estate investors [29]. Transparency in real estate increases accountability and quality of governance, and improving transparency plays a central role in providing healthy, productive and competitive environments for communities and businesses to thrive [31]. Further, in an effort to promote transparency, government initiatives can motivate towards more data digitization an openness with information [30], [32]. This suggests that technological advancements in the recent day can influence real estate development.

\subsubsection{Governance}

Governance, which supports participation of the private sector and local community in decision-making influence real estate development and sustainability [33]. Government can create an "enabling environment" for private sector investment and accelerate real estate development [34]. In addition, in some places, local governments have encouraged certain developments through changes in their land development code or through incentives for developers, who may or may not choose to respond [35]. Land use decisions are sometimes made by local governments, which have influential impacts on activity-friendly community environments. Further, government support that enforces constitutionally-driven community participatory model of development planning at the grassroots level is important [36], [37].

\subsection{Economic factors}

Economic factors were also considered important among the sampled studies. Economic uncertainty affects interest rates and monetary policy (lower-for longer) benefits real estate over other asset classes [5]. Economic conditions such as recession, unemployment rates and gross domestic product rates, as well as fiscal policies and regulations including interest rates and mortgage/lending environment, influence the rate at which investors and developers want to enter the real estate market [37], [38].

In addition, when planning regulations are tight, less housing construction will be initiated, because less land will be made available to investors [39]. Tighter regulations and restrictions on land use or density of development may affect investors' interest and the timing of proposed land development in the presence of uncertainty [20]. These forces may also produce a clustering and localized pattern of urbanization, where new development has tended to infill around existing development, as well as a dispersed trend [11]. Additionally, inadequate land policies and poor consultative processes result in inefficiencies in the process of making land available for housing development [40]. The difficulty in accessing development funds, underdeveloped mortgage market and high interest rates, land tenure arrangements, lengthy building permit/warrant approval and land acquisition and registration processes discourage real estate investments in Ghana [33]. Similarly, sound financial and economic structure, stability of the economy, restrictions and regulations on investors and legal regulation are the most important issues affecting the market attractiveness in Southeast Asian cities [41].

\subsection{Finance and related costs}

The most significant risk and uncertainty toward investment return is the income stream, in terms of the possible events that affect the income stream and uncertainties of the probability of the outcomes of these events. Access to capital and subsequent funding has an impact on the sustainability of real estate [16]. This is related to risk absorption and the availability of recourse to financial incentives to address the externalities. Planning considerations should therefore include tenant risk, demand and supply for the particular type of property being proposed, and in the particular location, the liquidity potential of the 
property, associated costs and expected benefits, delay premiums, and other assumptions that may lead to lower income than expected [15].

Further, as a result of housing supply constraints, high prices are a reflection of rising construction costs seen in more expensive materials like Canadian lumber or Chinese steel and a shortage-driven increase in labour costs [42]. The underlying cost of labor, land and materials in delivering the housing to the market is a concern. Lower financing costs and higher levels of transparency in real estate market attract greater amounts of real estate investment [41]. In addition, transaction and building material costs influence development in real estate [15], [20], [28].

A study by [39] revealed that the cost of construction variable has mostly been found to be insignificant in Ghana, partly because construction costs (as house prices) are influenced by housing supply levels and would generally decrease if the supply increases and demand remains the same. Conversely, in a recent study by the Price Water House Coopers [5], construction and land costs ranked the highest in importance among real estate development issues in the US real estate sector. Nevertheless, more reliance on local building materials and labour, which are more affordable could support and sustain the real estate sector in the provision of housing, as viewed [33], [36].

\subsection{Technology and innovation}

Technology and innovation were considered important in some of the literature examined. The few mentions could probably be due to the fact that advocating for the adoption of new technologies and disruptive innovation has only increased in recent times, with efforts geared towards the creation of smart cities. Innovation has made information available in real-time, changing the way real estate business is conducted [18]. While disruptive technologies are revolutionising the modern world, they present a challenge for traditional industries such as construction and real estate [17]. However, technological innovation and adoption of new digital technologies such as blockchain for land registries or 'smart' buildings, together with the digitisation of existing processes, offer opportunities to leapfrog the traditional routes to transparency and improve methods of collecting market data as well as transacting [30]. Digital reforms around land records and management can lead to greater access to land, reduced speculation, increased tenure security and, hence, more affordable housing also increases real estate development rates [35].

\subsection{Environmental factors}

Environmental sustainability is a concern in real estate development. Developers and investors are realizing that investing in available energy and water-saving technologies can produce low-risk returns creating more valuable and marketable real estate assets [18]. In relation to this, physical environment factors such as location and neighbourhood influence the market value of a specific investment [27]. Neighbourhood factors that may affect decision to invest and development patterns are safety, proximity to workplaces, travel time, sense of community, as well as affordability/value of properties in the area [35]. This suggests that the decision on location mainly depends on other factors such as accessibility to buyers' opportunities to support their needs (eg., places of education, worship, and shopping). For buyers who purchase for personal investment, locations that have the higher rental value will affect the investment or buying decision [43].

\subsection{Socio-cultural factors}

Social risks in commercial real estate development are mostly described in subjective forms. However. real estate development involves social-related risks and should be considered during the planning of such projects [15]. Furthermore, since smart city focuses on a continuous transformative process, based on stakeholder engagement and collaboration, and building different types of human, institutional and technical capacities, it is important to consider the local community and the potential impact of the development on their quality of life, capabilities and general wellbeing [23]. In addition, the participation of the community in the delivery of real estate projects would ensure acceptability of the projects [36]. Acceptability and cultural compatibility of proposed projects could be measured using degree of benefits, 
and public hygiene, using the degree of impacts on local public health and safety because of the development of specific projects [15].

\subsection{Rigid development patterns by private sector partners}

Although this factor occurred the least among the sampled literature, the role of developers as private sector to understand the persistence of conventional sprawl development and adopt sustainable alternatives to penetrate conventional markets has been emphasised. Developers have large control over the form and function of urban landscapes directly through construction activities that determine landscape configuration [44]. In some instances, the participation of the private developer is critical to making decisions about the desired function of a proposed development, as well as in the eventual success of real estate projects by the marketing strategies they use [35]. Desired functions on urban resilience within cities are closely related to land planning and development decisions that determine the composition and configuration of urban lands and the ecosystem services urban systems can provide [44]. Therefore, failure or unwillingness of developers to adopt new innovative alternatives to develop real estate is a concern. Further to this, competition may also have a significant effect on real estate development, especially commercial property, interacting with volatility so as to lower the value of the developer's option to defer its investment [20]

In summary, smart city development is complex. However, smart sustainable cities should include open government initiatives and environment to ensure access to data, stakeholder participation, leverage innovation, employ collaborative approaches and consider the impact of real estate developments on the populace who make use of the infrastructure. Further, in order to deliver real estate projects at reduced and affordable costs, while at the same time, ensuring that the objective of the developments are achieved and sustained in the long-run, the factors identified should be considered at the planning stage, which presents an opportunity to identify potential risks and alleviation strategies in the short and long-term.

\section{Summary and conclusion}

The current study set out to identify factors that could potentially affect the sustainability of real estate developments and thus should be considered at the planning stage of such projects. The findings were that institutional and economic factors were considered the most important, while developer's attitude and socio-cultural factors were the least occurring among the sampled literature. Since housing is a vital component of any economy, efforts should be made to identify risks, which may potentially hamper the success and sustainability of real estate development and the sector as a whole. The present study argued that identification of these factors at the ideation and planning stage of real estate developments would ensure that strategies are put in place to eliminate the occurrence of such risk or mitigate their impact on the success of projects.

The major limitation of the current study lies in the fact that it is a literature review and may not really reflect what the evidence in reality. Nonetheless, the use of relevant secondary data to distill information from primary research conducted on the subject, provides reliable evidence. The findings of the study are envisaged to be beneficial to real estate sector in developing strategies to manage the risks and implement policy.

\section{References}

[1] Ridzuan, M. M. and Ali, Z. (2012). Determining factors of corporate real estate (CRE) strategy implementation in the Malaysian business corporations, International Journal of Real Estate Studies, Volume 7, Number 1, 1-12 https://www.utm.my/intrest/files/2013/08/determining-factors-of-corporate-real-estate-cre-strategy-implementation-in-the-malaysianbusiness-corporations.pdf

[2] Yiyao, W. (2017). Real estate's contribution to GDP falling. Chana Daily. https://www.chinadaily.com.cn/business/201701/21/content_28017345.htm Accessed 22 November 2019

[3] Booth, P. M. and Marcato, G. (2003). The measurement and modelling of commercial real estate performance. Institute of Actuaries and Faculty of Actuaries. https://www.actuaries.org.uk/system/files/documents/pdf/sm20030922.pdf Accessed 22 November 2019

[4] Peng, L. (2017). Benchmarking Local Commercial Real Estate Returns: Statistics Meets Economics. https://doi.org/10.1111/15406229.12229

[5] PWC (2019). Emerging Trends in Real Estate: The global outlook for 2019. https://www.pwc.com/gx/en/industries/financialservices/assets/pwc-etre-global-outlook-2019.pdf Accessed 22 November 2019 
[6] Wallem, F. (2019). Smart cities for sustainable development and real estate strength.

https://www.academia.edu/8484669/Smart_Cities_for_Sustainable_Development_and_Real_Estate_Strength Accessed 27 November 2019

[7] Staff, W. P. J. (2019). New Home Construction, Buyer Traffic Rise in North America. World Property Journal. https://www.worldpropertyjournal.com/real-estate-news/united-states/dallas-real-estate-news/real-estate-news-nahb-new-homeconstruction-data-october-2019-lawrence-yun-nar-housing-data-greg-ugalde-lawrence-yun-11688.php Accessed 22 November 2019

[8] IOL (2012). Africa faces nightmare of urban sprawl IOL [online] https://www.iol.co.za/business-report/international/africa-facesnightmare-of-urban-sprawl-1326115 Accessed 23 November 2019

[9] United Nations Human Settlements Programme (UN-Habitat) (2016). Urbanization and development Emerging Futures. World Cities Report. http://nua.unhabitat.org/uploads/WCRFullReport2016_EN.pdf Accessed 23 November 2019

[10] Bibri, S. E. (2019). On the sustainability of smart and smarter cities in the era of big data: an interdisciplinary and transdisciplinary literature review. Journal of Big Data, 6(25): 1-64. https://doi.org/10.1186/s40537-019-0182-7

[11] Smersh, G. T., Smith, M. T. and Schwartz, A. L. (2003). Factors Affecting Residential Property Development Patterns, JRER, Vol. 25, No. $1: 61-75$ https://ssrn.com/abstract=981269

[12] Natasha, I. and Hassan, Z. (2016). Factors influencing property investment decisions among Employees in Felcra Bhd. International Journal of Accounting \& Business Management, 3(2): 160-177 https://doi.org/10.24924/ijabm/2015.11/v3.iss2/160.177

[13] Boudry, W. I., Connolly, R. A. and Steiner, E. (2018). What really happens during flight to safety: Evidence from real estate markets. Cornell University, School of Hotel Administration site: https://scholarship.sha.cornell.edu/workingpapers/47 Accessed 27 November 2019

[14] Boudry, W. I., Connolly, R. A. and Steiner, E. (2019). What happens during flight to safety: Evidence from public and private real estate markets. Real Estate Economics. https://doi.org/10.1111/1540-6229.12304

[15] Thilini, M. and Wickramaarachchi, N. C. (2019). Risk assessment in commercial real estate development: An application of analytic network process. Journal of Property Investment \& Finance, 37(5): 427-444 https://doi.org/10.1108/JPIF-01-2019-0002

[16] Roulac, S., Adair, A., McGreal, S., Berry J. and Allen, S. (2006). Real estate value: creation and destruction. Journal of Property Investment \& Finance, 24(6)No. 6, 2006 pp. 474-489 https://doi.org/10.1108/14635780610708293

[17] Ullah, F., Sepasgozar, S. M. E. and Wang, C. (2018). A systematic review of smart real estate technology: drivers of, and barriers to, the use of digital disruptive technologies and online platforms, Sustainability, 10, 3142: 1-44 https://doi.org/10.3390/su10093142

[18] Tiwari, P. and White, M. (2014). Real estate finance in the new economy. Wiley-Blackwell, United Kingdom

[19] Seth, S. (2017). The Most Important Factors for Investing in Real Estate https://www.investopedia.com/articles/investing/110614/most-important-factors-investing-real-estate.asp Accessed 26 November 2019

[20] Baldi, F. (2013). Valuing a greenfield real estate property development project: a real options approach. Journal of European Real Estate Research, Vol. 6 No. 2, 2013 pp. 186-217 https://doi.org/10.1108/JERER-06-2012-0018

[21] Caprotti, F. (2019). Spaces of visibility in the smart city: Flagship urban spaces and the smart urban imaginary, Urban Studies, Vol. 56(12) 2465-2479 https://doi.org/10.1177/0042098018798597

[22] Betancourt S. C. (2019). 'Smart cities' now 8.2\% the real estate market. https://www.onlinemarketplaces.com/articles/25768--Smartcities-now-8-2-the-real-estate-market Accessed 28 November 019

[23] Estevez, E., Lopes, N. V. and Janowski, T. (2016). Smart Sustainable Cities Reconnaissance Study. https://joinup.ec.europa.eu/sites/default/files/document/2016-04/smart_cities_report.pdf Accessed 28 November 2019

[24] Snyder, H. (20129). Literature review as a research methodology: An overview and guidelines. Journal of Business Research 104 (2019) 333-339 https://doi.org/10.1016/j.jbusres.2019.07.039

[25] De Souza, M. T., da Silva, M. D. and de Carvalho, R. (2010). Integrative review: what is it? How to do it? Einstein (São Paulo), 8(1) https://doi.org/10.1590/s1679-45082010rw1134

[26] Maclnnis, D. J. (2011). A Framework for Conceptual Contributions in Marketing. Journal of Marketing, 75: 136-154. https://doi.org/10.2139/ssrn. 1845968

[27] Adegoke. O. (2014). Critical factors determining rental value of residential property in Ibadan metropolis, Nigeria. Property Management, 32(3), 224-240. https://doi.org/10.1108/PM-05-2013-0033

[28] Delmendo, L. C. (2019). Nigeria's housing market stabilizing, amidst improving economic conditions. July 14, 2019 https://www.globalpropertyguide.com/Africa/Nigeria/Price-History Accessed 23 Nov 2019

[29] Edelstein, R., Qian, W. and Tsang, D. (2011). How Do Institutional Factors Affect International Real Estate Returns? Journal of Real Estate Finance and Economics, 2011: 1-32 https://doi.org/10.1007/s11146-010-9245-4

[30] Liedtke, S. (2018). Greater demand for transparency needed in African real estate industry, Engineering News, 20 sept 2018. https://m.engineeringnews.co.za/article/greater-demand-for-transparency-needed-in-african-real-estate-industry-2018-0920/rep_id:4433 Accessed 26 November 2019

[31] Eproperty News, (2018). Sub-Saharan Africa on a path to greater real estate transparency but progress is patchy. 24 September 2018 https://www.eprop.co.za/commercial-property-news/item/21392-sub-saharan-africa-on-a-path-to-greater-real-estatetransparency-but-progress-is-patchy.html Accessed 26 -11-2019

[32] WEF (2016). Shaping the Future of Construction A Breakthrough in Mindset and Technology. http://www3.weforum.org/docs/WEF_Shaping_the_Future_of_Construction_full_report_.pdf Accessed 02 November 2019

[33] Owusu-Ansah, A., Soyeh, K. W. and Asabere, P. A (2018). Developer constraints on housing supply in urban Ghana. International Journal of Housing Markets and Analysis Vol. 12 No. 1, 2019 pp. 59-73 https://doi.org/10.1108/lJHMA-07-2018-0052

[34] Gavu, E. K. and Owusu-Ansah, A. (2018). Empirical analysis of residential submarket conceptualisation in Ghana. International Journal of Housing Markets and Analysis ,Vol. 12 No. 4, 2019 pp. 763-787 https://doi.org/10.1108/JJHMA-10-2018-0080

[35] Carnoske, C., Hoehner, C., Ruthmann, N., Frank, L., Handy, S., Hill, J., Ryan, S., Sallis, J., Glanz, K. and Brownson, R. (2010). Developer and Realtor Perspectives on Factors That Influence Development, Sale, and Perceived Demand for Activity-Friendly Communities. J Phys Act Health. 2010 Mar; 7(0 1): S48-S59. https://doi.org/10.1123/jpah.7.s1.s48

[36] Williams, J. J. (2006). Community participation: Lessons from post-apartheid South Africa. Policy Studies, Vol. 27, No 3, 2006. https://doi.org/10.1080/01442870600885982

[37] Ramabodu, M. \& Zulch, Benita \& Verster, J.. (2007). Diversity and value in Africa's real estate: Challenges facing property development in South Africa. Journal of Property Investment \& Finance. 25. 7-22. https://doi.org/10.1108/14635780710720144. 
[38] Akinsomi, O., Mkhabela, N. and Taderera, M. (2017). The role of macro-economic indicators in explaining direct commercial real estate returns: Evidence from South Africa. Journal of Property Research, 35(1): 28-52. https://doi.org/10.1080/09599916.2017.1402071

[39] Owusu-Ansah, A. (2014). Modelling the supply of new residential construction in Aberdeen, UK. International Journal of Housing Markets and Analysis, 7 (3):. 346-362 https://doi.org/10.1108/IJHMA-07-2013-0043

[40] Bah, E. M., Faye, I. and Geh, Z. F. (2018). Unlocking Land Markets and Infrastructure Provision. Ch. 4 in: Housing Market Dynamics in Africa. pp 109-158, https://doi.org/10.1057/978-1-137-59792-2_4

[41] Gholipour, H. F, and Masron, T. A. (2013). Real estate market factors and foreign real estate investment, Journal of Economic Studies, 40(4): 448-468. https://doi.org/10.1108/JES-05-2011-0066

[42] Glaeser, E. and Gyourko, J. (2018). The economic implications of housing supply. Journal of Economic Perspectives, 32(1): 3-30. https://doi.org/10.1257/jep.32.1.3

[43] Ayedun, C., and Ignatus, O. (2013). An Examination of Estate Surveyors and Valuers' Perception of Flood Risk on Residential Property Value in Lagos State, Nigeria. Ethiopian Journal of Environmental Studies and Management, 6(6), 784. https://doi.org/10.4314/ejesm.v6i6.9S

[44] Turner, V. K. 2017. Obstacles to developing sustainable cities: the real estate rigidity trap. Ecology and Society 22(2):1. https://doi.org/10.5751/ES-09166-220201 